\title{
A Sensitive Monoclonal-Antibody-Based ELISA for Forchlorfenuron Residue Analysis in Food Samples
}

\author{
Xinmei Liu (D), Bo Xie, Yongjian Cheng, Lin Luo, Yifan Liang and Zhili Xiao *
}

Guangdong Provincial Key Laboratory of Food Quality and Safety, College of Food Science, South China Agricultural University, Guangzhou 510642, China; liuxinmei312@163.com (X.L.); xiebo950216@163.com (B.X.); 18815593698@163.com (Y.C.); lin.luo@scau.edu.cn (L.L.); yfliang0605@163.com (Y.L.)

* Correspondence: scauxzl@scau.edu.cn; Tel.: +86-20-85283448

\begin{abstract}
In this study, forchlorfenuron (CPPU) was coupled with succinic anhydride to yield a CPPU hapten $(\mathrm{CPPU}-\mathrm{COOH})$, and a high-affinity monoclonal antibody $(\mathrm{mAb})$ that can specifically recognize $\mathrm{CPPU}$ was produced. Using this $\mathrm{mAb}$ as a recognition reagent, a sensitive indirect competitive enzyme-linked immunosorbent assay (icELISA) for CPPU was optimized, which exhibits an $\mathrm{IC}_{50}$ of $1.04 \mathrm{ng} / \mathrm{mL}$, a limit of detection of $0.16 \mathrm{ng} / \mathrm{mL}$, and a linear range of $0.31-3.43 \mathrm{ng} / \mathrm{mL}$ for CPPU. Cross-reactivity percentages with six analogues were all below $6 \%$. The average recovery rates for cucumber and orange samples were from $85.23 \%$ to $119.14 \%$. The analysis results of this icELISA showed good consistency with those from liquid chromatography mass spectrometry. These results suggest that the proposed icELISA provides a sensitive, specific, and reliable strategy for CPPU detection in food samples.
\end{abstract}

Keywords: forchlorfenuron; monoclonal antibody; icELISA

check for updates

Citation: Liu, X.; Xie, B.; Cheng, Y.; Luo, L.; Liang, Y.; Xiao, Z. A Sensitive Monoclonal-Antibody-Based ELISA for Forchlorfenuron Residue Analysis in Food Samples. Biosensors 2022, 12, 78. https://doi.org/10.3390/ bios12020078

Received: 25 November 2021

Accepted: 24 January 2022

Published: 28 January 2022

Publisher's Note: MDPI stays neutral with regard to jurisdictional claims in published maps and institutional affiliations.

Copyright: (C) 2022 by the authors. Licensee MDPI, Basel, Switzerland. This article is an open access article distributed under the terms and conditions of the Creative Commons Attribution (CC BY) license (https:// creativecommons.org/licenses/by/ $4.0 /)$.

\section{Introduction}

Forchlorfenuron (CPPU) is a widely used plant growth regulator that can boost the yields of vegetable and fruit crops [1,2]. Several studies have reported that excessive intake of CPPU can potentially damage human health [3-5]. Zhu et al. [6] found that CPPU exposure can stimulate estradiol secretion, resulting in an earlier time of vaginal opening and first estrus time in prepubertal female rats. Gong et al. $[7,8]$ found that CPPU can induce cardiac morphology deformation and validated the cardiotoxicity of CPPU in a different experimental model. A chronic toxicity study on CPPU revealed its potentially negative effects on the ovaries [9]. In addition, long-term exposure to CPPU can induce acute and chronic intoxication and irritation to the eyes and skin [10]. Hence, to protect public health, many countries have issued a maximum residue limit (MRL) for CPPU. The MRL for CPPU in grapes and kiwifruit is $0.05 \mathrm{mg} / \mathrm{kg}$ in China, and $0.01 \mathrm{mg} / \mathrm{kg}$ in the European Union (EU). For cucumber and orange crops, the MRL is $0.1 \mathrm{mg} / \mathrm{kg}$ and $0.05 \mathrm{mg} / \mathrm{kg}$, respectively, in China, and $0.01 \mathrm{mg} / \mathrm{kg}$ for both crops in the EU [11,12].

Many techniques have been developed for the purpose of analyzing CPPU residue levels in food samples, such as Raman spectroscopy [3,13] and high-performance liquid chromatography (HPLC) [4,14-16]. Most of these techniques can achieve the sensitive and accurate quantification of CPPU; however, they are quite time-consuming and require expensive instruments operated by professional personnel. In comparison, immunoassays (IAs) possess the merit of being cost-effective; they use high-throughput screening, have high specificity, and simple sample preparation. They have become a favorable complement to the use of instrumental methods when screening large numbers of samples $[17,18]$.

Up to now, several IAs for the detection of CPPU have already been developed. AbadFuentes' group [19-21] synthesized a set of haptens against CPPU by introducing linear aliphatic spacers at different sites of the phenyl ring or the pyridyl ring in CPPU; all the 
haptens were able to induce high-affinity antisera to $\mathrm{CPPU}\left(\mathrm{IC}_{50}<1 \mathrm{nM}\right)$. A monoclonalantibody-based enzyme-linked immunosorbent assay (ELISA) for CPPU detection was developed with a limit of quantification of $5 \mu \mathrm{g} / \mathrm{kg}$ for kiwifruit, and a remarkable crossreactivity (CR) of $71 \%$ with the herbicide thidiazuron (TDZ) was observed. Lu et al. [22] synthesized an immunogen and a coating antigen (CPPU-H1-BSA, CPPU-H2-OVA) by referring to the strategy of Abad-Fuentes [21] and established a monoclonal antibody $\left(\mathrm{mAb}\right.$ )-based indirect competitive ELISA (icELISA) for CPPU. The $\mathrm{IC}_{50}$ was $3.89 \mathrm{ng} / \mathrm{mL}$. Compared with the hapten synthetic routes of Abad-Fuentes, which involve three to five steps of reactions, Xiao [23] reported a CPPU hapten synthesized through a more convenient strategy. The CPPU was coupled with succinic anhydride via a one-step Friedel-Crafts reaction, and a spacer arm was introduced on the phenyl ring of the CPPU. The hapten was conjugated with carrier proteins to obtain artificial antigens. An icELISA was established based on a rabbit polyclonal antibody. The $\mathrm{IC}_{50}$ was $48 \mathrm{ng} / \mathrm{mL}$, and the LOD was $1 \mathrm{ng} / \mathrm{mL}$.

In this study, we synthesized a hapten (CPPU-COOH) via a one-step modification in the CPPU described in previous work [23] and produced a mAb with high sensitivity and specificity to the CPPU. BSA, OVA, KLH, and THY were used as the carrier proteins of artificial antigens. Based on this $\mathrm{mAb}$, an icELISA for CPPU was characterized and optimized. The icELISA was applied in the determination of the CPPU levels in cucumber and orange samples, and its accuracy and reliability were validated by using LC-MS.

\section{Materials and Methods}

\subsection{Reagents and Instrumentals}

Reagents and instrumentals are presented in Supplementary Materials.

\subsection{Synthesis of Hapten}

The hapten CPPU-COOH was synthesized by coupling succinic anhydride with CPPU via a one-step Friedel-Crafts reaction as previously described [23]. Briefly, DMF (5 mL) was dropwise added to anhydrous $\mathrm{AlCl}_{3}(6.75 \mathrm{~g})$ under stirring at $0{ }^{\circ} \mathrm{C}$. After the $\mathrm{AlCl}_{3}$ was completely dissolved, CPPU (1.24 g) and succinic anhydride $(0.5 \mathrm{~g})$ were added to the reaction mixture and stirred at $50{ }^{\circ} \mathrm{C}$ for $6 \mathrm{~h}$. Next, the reaction mixture was poured into ice water $(60 \mathrm{~mL})$ with the addition of concentrated $\mathrm{HCl}(4 \mathrm{~mL})$. The precipitate was collected and washed with distilled water to yield a raw product. After recrystallization in DMF/methanol, the hapten CPPU-COOH was obtained and identified by LC-MS and ${ }^{1} \mathrm{H}$ NMR (Figure 1).

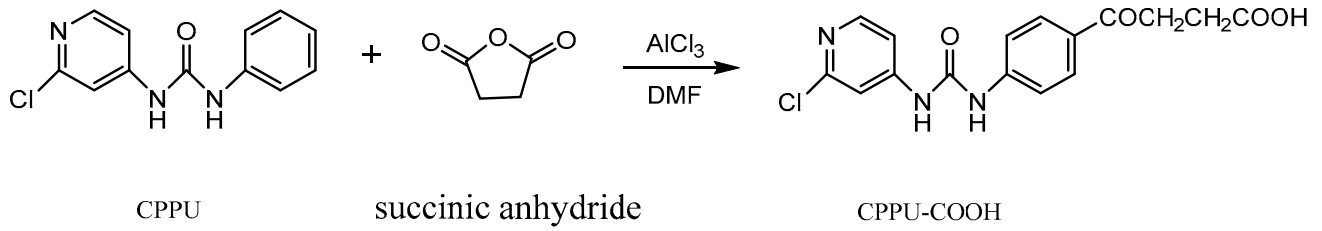

Figure 1. Synthesis route of the hapten. CPPU was coupled with succinic anhydride via Friedel-Crafts reaction, and a spacer arm was introduced on the phenyl ring of the CPPU.

\subsection{Preparation of Artificial Antigens}

Artificial antigens CPPU-COOH-OVA, CPPU-COOH-BSA, CPPU-COOH-KLH, and CPPU-COOH-THY were synthesized through active ester methods [24,25]. Briefly, CPPU$\mathrm{COOH}(0.04 \mathrm{mmol}), \mathrm{DCC}(0.05 \mathrm{mmol})$, and NHS $(0.05 \mathrm{mmol})$ were dissolved in DMF $(600 \mu \mathrm{L})$ and kept stirring at $4{ }^{\circ} \mathrm{C}$ for $12 \mathrm{~h}$. Then, the activated hapten was added to $5 \mathrm{~mL}$ of conjugate buffer (CBS) containing $50 \mathrm{mg}$ of carrier proteins. Next, the conjugate mixture was dialyzed against PBS $(10 \mathrm{mM}, \mathrm{pH} 7.4)$ at $4{ }^{\circ} \mathrm{C}$ for $72 \mathrm{~h}$, and finally stored at $-20^{\circ} \mathrm{C}$ for further use. 


\subsection{Production of $m A b$}

At the first immunization, each eight-week-old Balb/c female mouse was injected subcutaneously with $200 \mu \mathrm{L}$ of an emulsion containing an equal volume of immunogen $(1.0 \mathrm{mg} / \mathrm{mL})$ and Freund's complete adjuvant. In the subsequent booster immunizations, Freund's incomplete adjuvant was substituted for Freund's complete adjuvant and was injected at two-week intervals. After the third booster injection, the antisera were collected 7 days after each injection and checked by icELISA.

Hybridoma preparation procedures were performed as described previously [26]. The positive hybridoma cells were subcloned three to four times via the process of limiting dilution. The optimal antibody-generating clone was selected to generate ascetic antibodies. The anti-CPPU $\mathrm{mAb}$ was purified from ascites by the protein $\mathrm{G}$ affinity column method [27]. The subtype of the mAb was identified by using antibody isotyping kits.

\subsection{Optimization of ELISA Conditions}

The icELISA protocol was performed as described previously [28-30]. Briefly, $100 \mu \mathrm{L} /$ well of coating antigen $(1 \mu \mathrm{g} / \mathrm{mL}$ in CBS) was added to 96-well microtiter plates and stored at $37^{\circ} \mathrm{C}$ overnight. The plate was rinsed twice with washing buffer and blocked by PBST containing $5 \%$ skimmed milk powder $(120 \mu \mathrm{L} /$ well $)$ for $3 \mathrm{~h}$ at $37^{\circ} \mathrm{C}$. Then, the plate was rinsed twice and dried at $37^{\circ} \mathrm{C}$ for $60 \mathrm{~min}$. CPPU standard in PBS $(50 \mu \mathrm{L})$ and the antibodies diluted in PBS $(50 \mu \mathrm{L})$ were added and incubated at $37^{\circ} \mathrm{C}$ for $40 \mathrm{~min}$. After rinsing five times, the goat anti-mouse IgG-HRP was added (100 $\mu \mathrm{L} /$ well), followed by incubation for $30 \mathrm{~min}$ at $37^{\circ} \mathrm{C}$. After rinsing five times, the TMB solution $(100 \mu \mathrm{L} /$ well $)$ was added and incubated for another $10 \mathrm{~min}$ at $37^{\circ} \mathrm{C}$. Stopping reagent $(50 \mu \mathrm{L} /$ well $)$ was injected into each well to stop the chromogenic reaction, and the absorbance at $450 \mathrm{~nm}$ was measured using a microplate reader.

Many reports have shown that the immunoassay is an equilibrium binding reaction, and the experimental parameters used can affect the performance of the ELISA [28,31-33]. In order to improve sensitivity of the established icELISA, the assay was optimized on concentrations of coating antigen and antibody, working buffer, and IgG-HRP dilution multiple. A standard curve for CPPU was obtained under optimal conditions by fourparameter sigmoidal fitting with Origin 9.0 software (OriginLab Corporation, Northampton, MA, USA). The $\mathrm{IC}_{10}, \mathrm{IC}_{20}, \mathrm{IC}_{50}$, and $\mathrm{IC}_{80}$ values correspond to the CPPU concentration levels that inhibit $10 \%, 20 \%, 50 \%$, and $80 \%$ of the binding between $\mathrm{mAb}$ and the coating antigen, respectively. The $\mathrm{IC}_{10}$ value represents the LOD of the assay. The concentration levels from $\mathrm{IC}_{20}$ to $\mathrm{IC}_{80}$ are the linear range of the assay [27,34-36].

\subsection{Cross-Reactivity Test}

To evaluate the specificity of the mAb against CPPU, CR values with six structural analogs were chosen for evaluation. The CR values were calculated using Equation (1) [26,37]:

$$
\mathrm{CR}(\%)=\mathrm{IC}_{50 \mathrm{CPPU}} / \mathrm{IC}_{50} \text { structural analogue } \times 100
$$

\subsection{Detection of CPPU in Spiked and Real Samples}

Cucumber and orange samples obtained from a local supermarket were detected as CPPU-negative by LC-MS analysis. The negative samples were spiked with series concentrations of CPPU for a recovery test. Eight blind samples were also chosen to be tested with both icELISA and LC-MS.

The samples were pretreated according to the Chinese National Standard method for CPPU detection in foods with some modifications [38]. A $10.00 \mathrm{~g}$ sample was mixed with $10.0 \mathrm{~mL}$ of acetonitrile and extracted for $3 \mathrm{~min}$, then $4.0 \mathrm{~g}$ of anhydrous magnesium sulfate and $1.0 \mathrm{~g}$ of sodium chloride were added and shaken for $1 \mathrm{~min}$ followed by a centrifugation (4000 r/min, $5 \mathrm{~min})$. An amount of $8.0 \mathrm{~mL}$ of the supernatants was mixed with $200 \mathrm{mg}$ of primary secondary amine (PSA), $50 \mathrm{mg}$ of graphitized carbon black (GCB), and $700 \mathrm{mg}$ anhydrous magnesium sulfate, then extracted for $2 \mathrm{~min}$, followed by a centrifugation 
(4000 r/min, $5 \mathrm{~min}$ ). The final supernatants were filtered through $0.22 \mu \mathrm{m}$ membrane before being analyzed by the established icELISA. The accuracy of the method was validated by LC-MS. Chromatographic separation was achieved in an Eclipse plus $\mathrm{C}_{18}$ column $(2.1 \times 50 \mathrm{~mm}$, Agilent Technologies, Santa Clara, CA, USA $)$ at a flow rate of $0.4 \mathrm{~mL} / \mathrm{min}$ (mobile phase A was 10\% methanol; mobile phase B was pure acetonitrile). The injection volume was $1 \mu \mathrm{L}$. The samples were quantified by ESI in the positive mode.

\section{Results and Discussion}

\subsection{Hapten Synthesis and Artificial Antigen Preparation}

CPPU is a small molecule (Mw $<1000 \mathrm{Da})$ without immunogenicity. Hapten design and synthesis are crucial processes in the development of specific antibodies. A complicated synthetic route may lead to decreasing yield and purity. In this study, one hapten (CPPU$\mathrm{COOH}$ ) was synthesized via a Friedel-Crafts reaction to introduce a four-carbon spacer arm at the phenyl ring of CPPU and identified by electrospray ionization mass spectrometry (ESI-MS) and NMR. As shown in the mass spectrum (Figure S1), the highest peak at $\mathrm{m} / \mathrm{z}$ 349 was consistent with the mass-to-charge ratio of the parent ion of CPPU-COOH. The ${ }^{1} \mathrm{H}$ NMR spectrum of CPPU-COOH (Figure S2) revealed the presence of two methylene groups $\left(\delta_{\mathrm{H}} 3.20(\mathrm{t}, \mathrm{J}=6.3 \mathrm{~Hz}, 2 \mathrm{H})\right.$ and $\left.2.56(\mathrm{t}, \mathrm{J}=6.3 \mathrm{~Hz}, 2 \mathrm{H})\right)$, which correspond to two methylene groups from succinic anhydride. The proton signals at $\delta_{\mathrm{H}} 7.96(\mathrm{~d}, \mathrm{~J}=8.7 \mathrm{~Hz}$, $2 \mathrm{H})$ and $7.61(\mathrm{~d}, \mathrm{~J}=8.8 \mathrm{~Hz}, 2 \mathrm{H})$ can be attributed to these four protons at the phenyl ring of hapten CPPU-COOH. The proton signals at $\delta_{\mathrm{H}} 8.20(\mathrm{~d}, \mathrm{~J}=5.7 \mathrm{~Hz}, 1 \mathrm{H}), 7.66(\mathrm{~d}, \mathrm{~J}=1.9 \mathrm{~Hz}$, $1 \mathrm{H})$, and $7.35(\mathrm{dd}, \mathrm{J}=5.7,1.9 \mathrm{~Hz}, 1 \mathrm{H})$ can be attributed to these three protons at the pyridyl ring of CPPU-COOH. The proton signals of the carboxyl group in CPPU-COOH are matched with $\delta_{\mathrm{H}} 12.14(\mathrm{~s}, 1 \mathrm{H})$. The proton signals at $\delta_{\mathrm{H}} 9.48(\mathrm{~s}, 1 \mathrm{H})$, and $9.40(\mathrm{~s}, 1 \mathrm{H})$ can be attributed to the two protons of ureido in CPPU-COOH. These results indicated the successful synthesis of CPPU-COOH.

To produce a specific antibody, haptens should be coupled with proteins to form artificial antigens with both immunogenicity and immunoreactivity. BSA and OVA are commonly used proteins. In this study, BSA, KLH, and THY were selected as carriers and conjugated with CPPU hapten to obtain immunogens; BSA and OVA were chosen as substrates to obtain coating immunoreagents. The designed hapten CPPU-COOH contained a carboxyl group by which CPPU-COOH could be conjugated with amine groups in carrier proteins via the active ester method. The hapten-protein conjugates were characterized by UV spectrophotometry (Figure 2). As shown in Figure 2, CPPU$\mathrm{COOH}$ has a characteristics absorption peak at $295 \mathrm{~nm}$, whereas BSA, KLH, THY, and OVA displayed the characteristic absorption peak of proteins at $\sim 280 \mathrm{~nm}$. The obtained hapten-protein conjugates, CPPU-COOH-BSA, CPPU-COOH-KLH, CPPU-COOH-THY, and CPPU-COOH-OVA contained a distinct absorption peak at $\sim 295 \mathrm{~nm}$, which indicated that CPPU-COOH was successfully conjugated to the carrier protein [39].

\subsection{Antisera and Coating Antigens Combination Selection}

The titer and specificity of the antisera were assessed via icELISA. As shown in Table 1, antisera induced by immunogens CPPU-COOH-BSA and CPPU-COOH-KLH showed relatively low affinity to CPPU with lower inhibition rates $(<55.9 \%)$, while antisera from immunogen CPPU-COOH-THY showed a significantly higher titer and inhibition rate than those of CPPU-COOH-BSA and CPPU-COOH-KLH. When using CPPU-COOH-BSA as a coating antigen, the inhibition rate was $83.3 \%$ to CPPU $(1 \mu \mathrm{g} / \mathrm{mL})$. As reported previously, THY was selected as a carrier protein of immunogen for its high immunogenicity [40-42]. CPPU-COOH-BSA and CPPU-COOH-THY were chosen for mAb production and the development of the icELISA. 

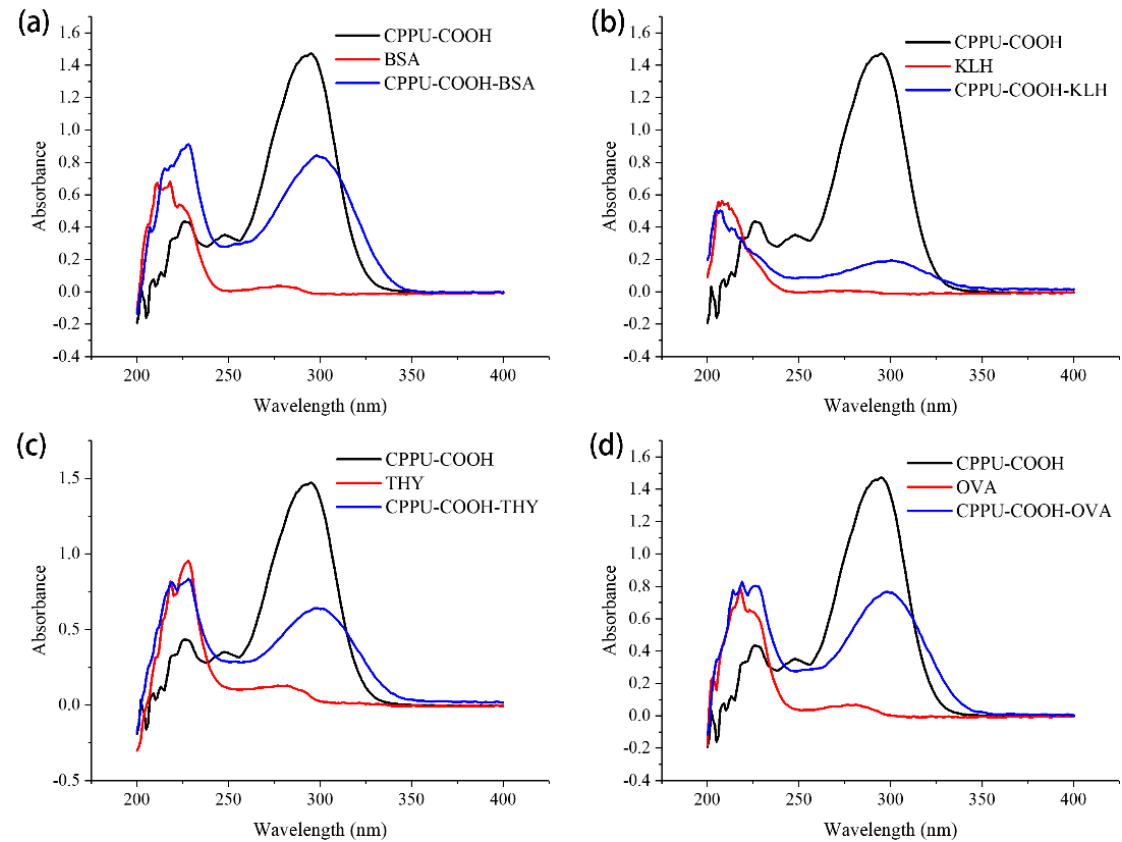

Figure 2. UV spectra of hapten, carrier proteins, and artificial antigens. (a) CPPU-COOH-BSA; (b) CPPU-COOH-KLH; (c) CPPU-COOH-THY; (d) CPPU-COOH-OVA. CPPU-COOH-BSA, CPPU$\mathrm{COOH}-\mathrm{KLH}, \mathrm{CPPU}-\mathrm{COOH}-\mathrm{THY}$, and CPPU-COOH-OVA exhibited a distinct pattern of absorbance, reflecting properties of the carboxyl on the hapten to amino groups of the carrier protein.

Table 1. Characterization of mice antisera against CPPU with different coating antigens.

\begin{tabular}{|c|c|c|c|c|c|c|}
\hline \multirow{2}{*}{$\begin{array}{c}\text { Immunogen } \\
\text { Coating } \\
\text { Antigens }\end{array}$} & \multicolumn{2}{|c|}{ CPPU-СООН-BSA } & \multicolumn{2}{|c|}{ CPPU-COOH-KLH } & \multicolumn{2}{|c|}{ CPPU-СООН-ТHY } \\
\hline & $\operatorname{Titer}^{\mathrm{a}}\left(10^{3}\right)$ & $\begin{array}{l}\text { Inhibition }{ }^{b} \\
\text { of CPPU (\%) }\end{array}$ & Titer $^{a}\left(10^{3}\right)$ & $\begin{array}{l}\text { Inhibition }{ }^{b} \\
\text { of CPPU (\%) }\end{array}$ & $\begin{array}{l}\text { Titer }{ }^{\mathrm{a}} \\
\left(10^{3}\right)\end{array}$ & $\begin{array}{l}\text { Inhibition }{ }^{b} \\
\text { of CPPU (\%) }\end{array}$ \\
\hline CPPU-COOH-BSA & - & - & 16 & 55.6 & 32 & 83.3 \\
\hline CPPU-COOH-OVA & 32 & 58.4 & 8 & 55.9 & 16 & 82.9 \\
\hline
\end{tabular}

${ }^{b}$ Inhibition $=\left[\left(B-B_{0}\right) / B\right] \times 100 \%$, at $1 \mu \mathrm{g} / \mathrm{mL}$ of competitor $[25,43]$.

\subsection{Production of $m A b$ and Establishment of icELISA}

According to the results of the antisera detection, the mice immunized by CPPU$\mathrm{COOH}-\mathrm{THY}$ were selected for cell fusion. After four rounds of screening, the CPPU-specific $\mathrm{mAb}$ was produced from a selected hybridoma (CPPU-a). The subtype of the $\mathrm{mAb}$ was immunoglobulin $G_{1}$ type. To enhance the assay sensitivity and stability, three parameters were optimized. The $\mathrm{A}_{\max } / \mathrm{IC}_{50}$ ratio was used as the index for evaluating the influence of each condition; a higher ratio demonstrates a higher level of sensitivity in the assay [44-47]. The optimized results are shown in Figure 3. The $A_{\max }$ was the highest at $500 \mathrm{ng} / \mathrm{mL}$ of coating antigen and it decreased as the coating concentration became lower. Usually, a higher coating concentration can result in a higher $\mathrm{A}_{\max }$ value, but an overly high coating concentration may cause mutual interference or increase non-specific adsorption when the immobilized coating antigen binds with the antibody, so the absorbance value may decrease after the blank value is subtracted. The $\mathrm{IC}_{50}$ gradually decreased as the content of the coating antigen and the antibody reduced and was the lowest at a coating concentration of $250 \mathrm{ng} / \mathrm{mL}$ and an antibody with 1:8000 dilution $(1 \mu \mathrm{g} / \mathrm{mL})$. The $\mathrm{A}_{\max } / \mathrm{IC}_{50}$ ratio was also the highest at this concentration combination. So, these were chosen as the optimal working concentrations. The efficiency of icELISA can also be influenced by physicochemical factors related to the buffer [48]. The $\mathrm{A}_{\max }$ and $\mathrm{IC}_{50}$ values varied when PBS, PBST, or Tris- $\mathrm{HCl}$ was used as a dilution solution of a standard analyte and antibodies. The $\mathrm{A}_{\max } / \mathrm{IC}_{50}$ was more efficacious with PBS than with PBST or Tris- $\mathrm{HCl}$ with moderate $\mathrm{A}_{\max }$ and the 
lowest $\mathrm{IC}_{50}$. This indicated that PBS is more suitable for the reaction system of this assay. The IgG-HRP was diluted from 1:2000 to 1:5000, and the highest $A_{\max }$ with the second lowest $\mathrm{IC}_{50}$ were observed at the dilution multiple of 1:5000, which displayed the highest $\mathrm{A}_{\max } / \mathrm{IC}_{50}$ proportion. In an icELISA system, the content of the coating antigen, antibody, and secondary antibody (IgG-HRP) have a comprehensive effect on the sensitivity of the assay, so they should be optimized in accordance with each other. Under the optimum conditions, an icELISA standard curve was fitted. The $\mathrm{IC}_{50}$ value for CPPU was $1.04 \mathrm{ng} / \mathrm{mL}$, the LOD was $0.16 \mathrm{ng} / \mathrm{mL}$, and the linear range was between 0.31 and $3.43 \mathrm{ng} / \mathrm{mL}$ (Figure 4).

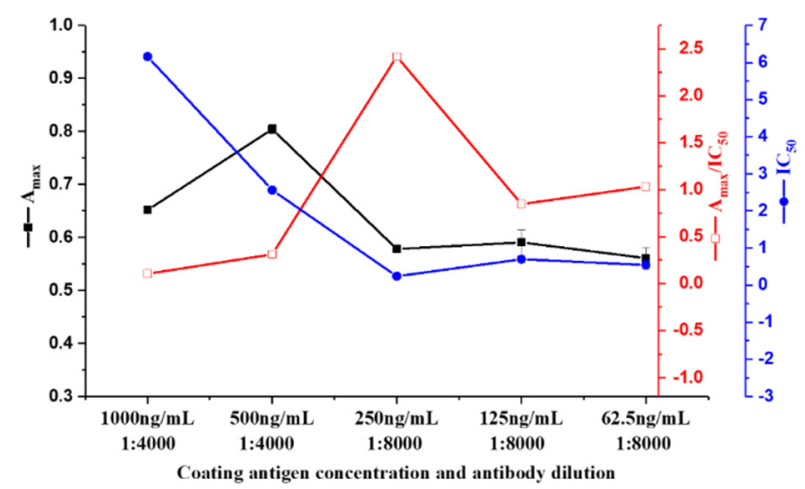

(a)

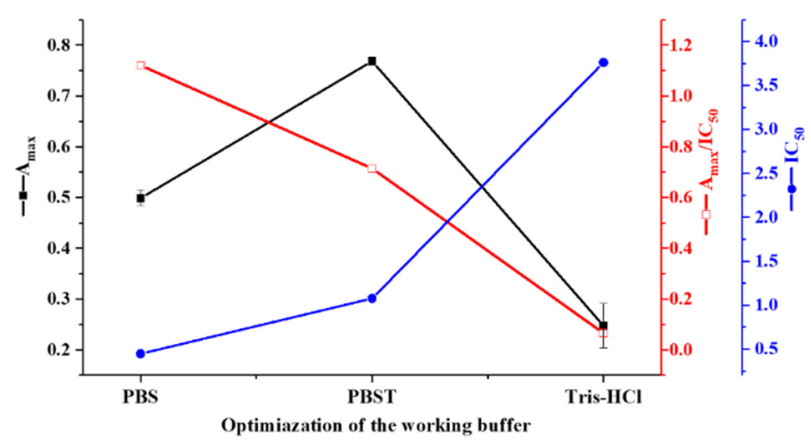

(b)

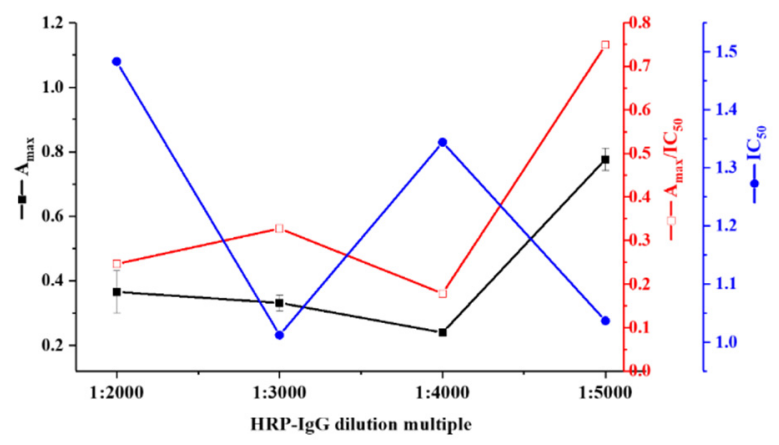

(c)

Figure 3. The optimized reaction conditions for icELISA $(n=3)$. (a) Concentration of coating antigen and antibody; (b) working buffer for the analyte; (c) IgG-HRP dilution multiple. The coating antigen at a concentration of $250 \mathrm{ng} / \mathrm{mL}$, the antibody with a 1:8000 dilution $(1 \mu \mathrm{g} / \mathrm{mL})$, PBS as a dilution solution, and IgG-HRP diluted 1:5000 were chosen as the optimal working conditions. 


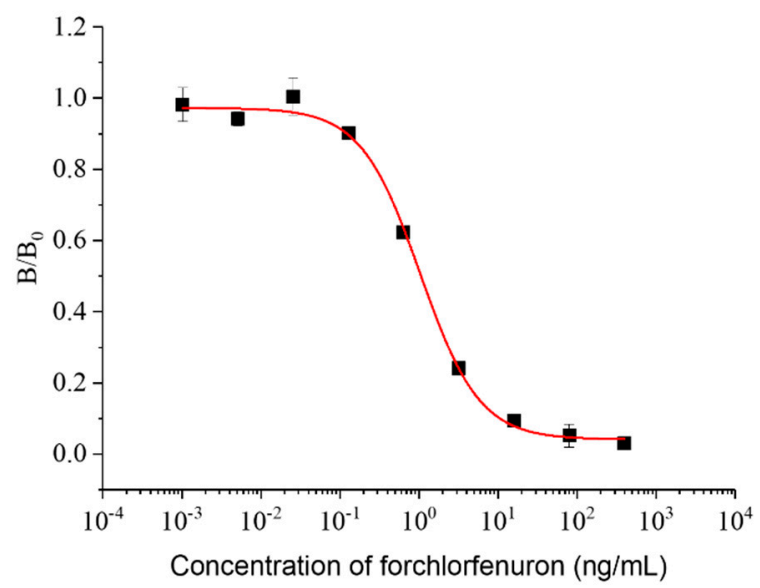

Figure 4. Standard curve for icELISA $(n=3)$. The $\mathrm{IC}_{50}$ for CPPU was $1.04 \mathrm{ng} / \mathrm{mL}$, the LOD was $0.16 \mathrm{ng} / \mathrm{mL}$, and the linear range was $0.31-3.43 \mathrm{ng} / \mathrm{mL}$.

\subsection{Cross-Reactions}

The cross-reactivity (CR) is inversely related with the specificity. The CR was evaluated through $\mathrm{IC}_{50}$ of six CPPU structural analogues (Table 2). Low CR values were observed in the six listed compounds, which demonstrated that the mAb was specific and sensitive to CPPU. In a previous study [21], a CR with thidiazuron (TDZ) of 71\% was observed, while in this study, the CR was 5.36\% with TDZ and below $2 \%$ with the other analogues. This further confirmed the high specificity of the anti-CPPU mAb, which is vital to the established ELISA reaction system.

Table 2. Cross-reactivity of CPPU and other structural analogues.

Analyte Cross-Reactivity (\%)


Table 2. Cont.

Analyte

\subsection{Detection of CPPU in Spiked and Real Samples}

Generally, dilution of the sample can reduce the matrix effects on an immunoassay to a large extent $[49,50]$. In this study, spiked cucumber and orange samples were analyzed using icELISA. When diluted by PBS containing 5\% acetonitrile to twenty-fold, the matrix effects were effectively eliminated (Figure 5).

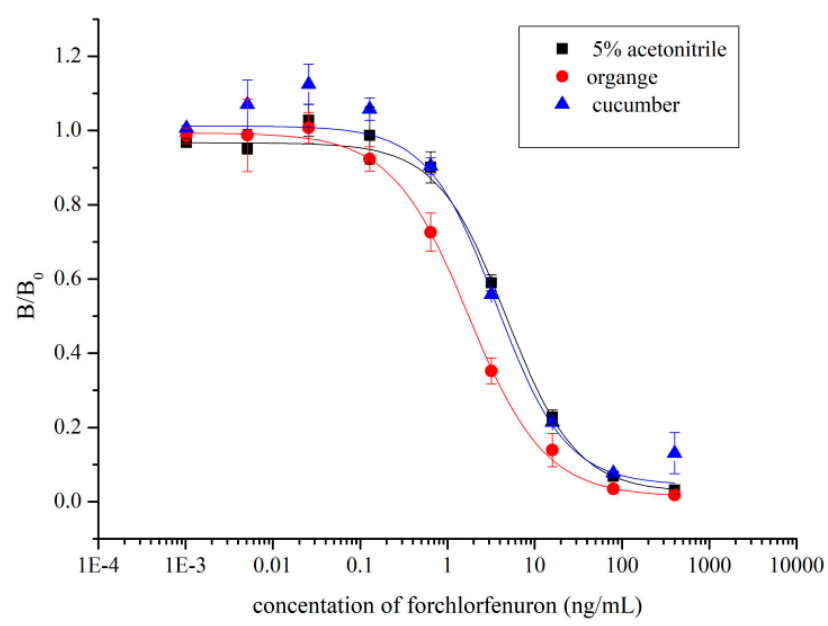

Figure 5. Matrix effects of cucumber and orange samples $(n=3)$. Standard curves were fitted using PBS containing $5 \%$ acetonitrile, spiked orange matrix (diluted with PBS containing $5 \%$ acetonitrile to twenty-fold), and spiked cucumber matrix (diluted with PBS containing 5\% acetonitrile to twentyfold). The three curves nearly overlap.

Three different concentrations of CPPU were spiked in cucumber and orange samples and validated by icELISA. The average recovery rates of the samples were from $85.23 \%$ to $119.14 \%$ (Table 3 ), and the coefficients of variation $(\mathrm{CV})$ were less than $10 \%$. 
Table 3. Recoveries of CPPU-spiked food samples determined by icELISA $(n=3)$.

\begin{tabular}{ccccc}
\hline Samples & Spiked (ng) & Measured \pm SD (ng/g) & Recovery (\%) & CV (\%) \\
\hline \multirow{2}{*}{ Cucumber } & 40 & $38.70 \pm 0.16$ & 96.80 & 8.33 \\
& 80 & $79.00 \pm 0.25$ & 98.80 & 6.25 \\
Orange & 160 & $159.20 \pm 0.40$ & 99.60 & 5.01 \\
& 40 & $47.60 \pm 0.14$ & 119.14 & 6.21 \\
\end{tabular}

Eight real samples were selected for detection with icELISA and the results were confirmed by LC-MS. As shown in Table 4, cucumbers number 1 and 3 and orange number 4 were detected positive by the established icELISA method. Good correlations were observed between icELISA and LC-MS, proving the high accuracy and reliability of the established icELISA method for CPPU quantitative determination in food samples.

Table 4. Comparison between icELISA and LC-MS quantitative results for CPPU residues in cucumbers and oranges.

\begin{tabular}{|c|c|c|c|c|c|}
\hline \multirow{2}{*}{ Sample } & \multirow{2}{*}{ Number } & \multicolumn{2}{|c|}{ icELISA } & \multicolumn{2}{|c|}{ LC-MS } \\
\hline & & $\mathrm{ng} / \mathrm{mL}$ & ng/g & $\mathrm{ng} / \mathrm{mL}$ & $\mathrm{ng} / \mathrm{g}$ \\
\hline \multirow{4}{*}{ Cucumber } & 1 & 5.12 & 102.4 & 5.17 & 103.4 \\
\hline & 2 & ND & ND & 0.13 & 2.6 \\
\hline & 3 & 1.96 & 39.2 & 2.62 & 52.4 \\
\hline & 4 & ND & ND & 0.12 & 2.4 \\
\hline \multirow{4}{*}{ Orange } & 1 & ND & ND & 0.14 & 2.8 \\
\hline & 2 & ND & ND & 0.06 & 1.2 \\
\hline & 3 & ND & ND & 0.13 & 2.6 \\
\hline & 4 & 0.32 & 6.4 & 0.35 & 7.0 \\
\hline
\end{tabular}

ND: Not detected.

\section{Conclusions}

In this study, a high-affinity and specific $\mathrm{mAb}$ against $\mathrm{CPPU}$ was produced and an icELISA was established for reliable CPPU residue analysis in food. The spiked and real food samples were analyzed with the icELISA, and the accuracy of the method was confirmed by LC-MS.

A hapten synthesis route with more simplicity and efficiency than previously reported methods [19-22] was utilized. With the mAb generated and the ELISA developed, CPPU was able to be detected at $0.16 \mathrm{ng} / \mathrm{mL}(3.2 \mu \mathrm{g} / \mathrm{kg}$ in food $)$. The $\mathrm{IC}_{50}(1.04 \mathrm{ng} / \mathrm{mL}$ or $4.2 \mathrm{nM}$ ) was higher than that of the Abad-Fuentes group $\left(\mathrm{IC}_{50}<1 \mathrm{nM}\right)$; however, they obtained a limit of quantification of $5 \mu \mathrm{g} / \mathrm{kg}$ for kiwifruit, slightly higher than in this assay. They also reported a CR of $71 \%$ with the herbicide TDZ [21], while with this method, the CRs with TDZ and five other CPPU structural analogues were all less than $6 \%$. Xiao [23] coupled CPPU with succinic anhydride via a one-step Friedel-Crafts reaction for the first time. IcELISA was developed by using a rabbit polyclonal antibody. The $\mathrm{IC}_{50}(48 \mathrm{ng} / \mathrm{mL})$ and LOD $(1 \mathrm{ng} / \mathrm{mL})$ were both far higher than in this assay. In this study, we designed the synthesis route of hapten while referring to the synthetic method of Xiao. BSA (for immunogen) paired with OVA (for coating) were selected as carriers in previous studies [19-23]. In our work, KLH and THY were also selected as carriers for obtaining immunogens and compared to BSA. We found that antisera from THY immunogen showed significantly higher titer and inhibition rates than those from BSA and KLH, which indicated that carrier selection may be an effective way to improve CPPU antibody performance. A monoclonal antibody-based immunoassay is ideal for CPPU monitoring, due to its satisfactory accuracy, rapidity, and cost-effectiveness. Furthermore, this work aims to promote the application of more IAs in CPPU and in the detection of other agrochemicals. 
Supplementary Materials: The following supporting information can be downloaded at: https: / / www.mdpi.com/article/10.3390/bios12020078/s1, Reagents and Instrumentals; Figure S1: The MS spectrum of CPPU-COOH; Figure S2: The NMR spectrum of CPPU-COOH.

Author Contributions: Conceptualization, X.L.; data curation, X.L., B.X. and Y.C.; formal analysis, L.L. and Y.L.; supervision, Z.X.; Writing-original draft preparation, X.L.; Writing-review and editing, Z.X. All authors have read and agreed to the published version of the manuscript.

Funding: This work was supported by the National Key Research and Development Program of China (2018YFC1602903) and Guangdong Basic and Applied Basic Research Foundation (2019A1515012107)

Institutional Review Board Statement: The animal study protocol was approved by the Institutional Ethics Committee for Laboratory Animal (protocol code 2019007 and approval date 23 January 2019).

Informed Consent Statement: Not applicable.

Data Availability Statement: Not applicable.

Conflicts of Interest: All authors declare no conflict of interest in this paper.

\section{References}

1. Arena, M.; Auteri, D.; Barmaz, S.; Bellisai, G.; Brancato, A.; Brocca, D.; Bura, L.; Byers, H.; Chiusolo, A.; Marques, D.C.; et al. Peer review of the pesticide risk assessment of the active substance forchlorfenuron. EFSA J. 2017, 15, 4874. [CrossRef]

2. U.S. Environmental Protection Agency. Pesticide Fact Sheet, Forchlorfenuron. 2004. Available online: https://www3.epa.gov/ pesticides/chem_search/reg_actions/registration/fs_PC-128819_01-Sep-04.pdf (accessed on 20 November 2021).

3. Chen, X.M.; Yan, K.L.; Xiao, X.H.; Li, G.K. Analysis of forchlorfenuron and thidiazuron in fruits and vegetables by surfaceenhanced Raman spectroscopy after selective solid-phase extraction with modified $\beta$-cyclodextrin. J. Sep. Sci. 2016, 39, $2340-2346$. [CrossRef] [PubMed]

4. Hu, J.T.; Yu, L.Y.; Shuai, P.Q.; Yu, G.; He, K.R. Determination of Forechlorfenuron Residue in Fruits and Vegetables by QuEChERS Extraction and HPLC-MS/MS. Agric. Sci. Technol. 2017, 18, 1686-1690. [CrossRef]

5. Ping, L.; Xu, B.; Zhou, Q.; Hong, Y.; Sun, Q.; Wang, J.; Zhu, D. Comparative pharmacokinetic study of Forchlorfenuron in adult and juvenile rats. Molecules 2021, 26, 4276. [CrossRef]

6. Zhu, D.F.; Ping, L.; Shen, X.F.; Hong, Y.W.; Weng, Q.J.; He, Q.J.; Wang, J.J. Effects of prepubertal exposure to forchlorfenuron through prenatal and postnatal gavage administration in developing Sprague-Dawley rats. Reprod. Toxicol. 2020, 98, 9. [CrossRef]

7. Gong, G.; Kam, H.; Tse, Y.; Lee, S.M. Cardiotoxicity of forchlorfenuron (CPPU) in zebrafish (Danio rerio) and H9c2 cardiomyocytes. Chemosphere 2019, 235, 153-162. [CrossRef]

8. Gong, G.; Kam, H.; Tse, Y.; Giesy, J.; Seto, S.; Lee, S.M. Forchlorfenuron (CPPU) causes disorganization of the cytoskeleton and dysfunction of human umbilical vein endothelial cells, and abnormal vascular development in zebrafish embryos. Environ. Pollut. 2021, 271, 115791. [CrossRef]

9. Bu, Q.; Wang, X.Y.; Xie, H.C.; Zhong, K.; Wu, Y.P.; Zhang, J.Q.; Wang, Z.S.; Gao, H.; Huang, Y.N. 180 day repeated-dose toxicity study on forchlorfenuron in SpragueDawley rats and its effects on the production of steroid hormones. J. Agric. Food Chem. 2019, 67, 10207-10213. [CrossRef]

10. Li, M.H.; Guo, X.D.; Chen, Y.J.; Zhang, K.; Bai, Q.; Gao, Z.P.; Long, F.Y. The degradation of forchlorfenuron in the model kiwifruit juice by ultrasonic treatment. J. Food Processing Preserv. 2020, 44, e14424. [CrossRef]

11. European Commission. Pesticides Residues. No 398/2014 Annex II. Available online: https:/ / eur-lex.europa.eu/legal-content/ EN/TXT/PDF/?uri=CELEX:32014R0398\&from=EN (accessed on 20 November 2021).

12. National Food Safety Standard-Maximum Residue Limits for Pesticides in Food. Available online: https://agrochemical. chemlinked.com/sites/default/files/preview-doc/sample_translation_of_gb2763-2019.pdf (accessed on 20 November 2021).

13. Lu, D.; Zhao, W.; Gao, G.; Meng, Y.; Zeng, X.; Wu, N.; Lei, Y. Raman spectroscopy analysis of Forchlorfenuron based on two-dimensional correlation technique. Spectrosc. Spectr. Anal. 2019, 39, 1464-1467. [CrossRef]

14. Li, P.; Lu, Y.; Cao, J.; Li, M.; Yang, C.; Yan, H. Imidazolium ionic-liquid-modified phenolic resin for solid-phase extraction of thidiazuron and forchlorfenuron from cucumbers. J. Chromatogr. A 2020, 1623, 461192. [CrossRef] [PubMed]

15. Xu, X.; Hou, X.; Han, M.; Qiu, S.; Li, Y. Simultaneous determination of multiclass plant growth regulators in fruits using the quick, easy, cheap, effective, rugged, and safe method and ultra-high performance liquid chromatography-tandem mass spectrometry. $J$. Sep. Sci. 2020, 43, 788-798. [CrossRef]

16. Ren, Y.; Xiang, P.; Xie, Q.; Yang, H.; Liu, S. Rapid analysis of forchlorfenuron in fruits using molecular complex-based dispersive liquid-liquid microextraction. Food Addit. Contam. A 2021, 38, 637-645. [CrossRef] [PubMed]

17. Wang, J.P.; Yu, G.C.; Sheng, W.; Shi, M.; Guo, B.X.; Wang, S. Development of an enzyme-linked immunosorbent assay based a monoclonal antibody for the detection of pyrethroids with phenoxybenzene multiresidue in river water. J. Agric. Food Chem. 2011, 59, 2997-3003. [CrossRef] [PubMed] 
18. Lee, N.A.; Wang, S.; Allan, R.D.; Kennedy, I.R. A Rapid Aflatoxin B1 ELISA: Development and Validation with Reduced Matrix Effects for Peanuts, Corn, Pistachio, and Soybeans. J. Agric. Food Chem. 2004, 52, 2746-2755. [CrossRef]

19. Suárez-Pantaleón, C.; Mercader, J.V.; Agulló, C.; Abad-Somovilla, A.; Abad-Fuentes, A. Production and Characterization of Monoclonal and Polyclonal Antibodies to Forchlorfenuron. J. Agric. Food Chem. 2008, 56, 11122-11131. [CrossRef]

20. Suárez-Pantaleón, C.; Mercader, J.V.; Agulló, C.; Abad-Somovilla, A.; Abad-Fuentes, A. Hapten Synthesis and Polyclonal Antibody-Based Immunoassay Development for the Analysis of Forchlorfenuron in Kiwifruit. J. Agric. Food Chem. 2010, 58, 8502-8511. [CrossRef]

21. Suárez-Pantaleón, C.; Esteve-Turrillas, F.A.; Mercader, J.V.; Agulló, C.; Abad-Somovilla, A.; Abad-Fuentes, A. Development and validation of a direct competitive monoclonal antibody-based immunoassay for the sensitive and selective analysis of the phytoregulator forchlorfenuron. Anal. Bioanal. Chem. 2012, 403, 2019-2026. [CrossRef]

22. Lu, J.K.; Ai, M.Y.; Li, S.G. Preparation of anti-CPPU monoclonal antibody and development of an indirect competitive ELISA method. Hubei Agric. Sci. 2016, 55, 5584-5587. [CrossRef]

23. Xiao, S.M. The Establishment of Gold Nanoparticles-Colorimetric and Immunoassay Analysis Method on Detection of Pesticide Residues in Environment and Food. Master's Thesis, Nanchang University, Nanchang, China, 2017.

24. Ni, T.T.; Peng, D.P.; Wang, Y.X.; Pan, Y.H.; Chen, D.M.; Wang, Y.L.; Tao, Y.F.; Yuan, Z.H. Development of a broad-spectrum monoclonal antibody-based indirect competitive enzyme-linked immunosorbent assay for the multi-residue detection of avermectins in edible animal tissues and milk. Food Chem. 2019, 286, 234-240. [CrossRef]

25. Chen, Z.J.; Liu, X.X.; Xiao, Z.L.; Fu, H.J.; Huang, Y.P.; Huang, S.Y.; Shen, Y.D.; He, F.; Yang, X.X.; Hammock, B.D.; et al. Production of a specific monoclonal antibody for 1-naphthol based on novel hapten strategy and development of an easy-to-use ELISA in urine samples. Ecotoxicol. Environ. Saf. 2020, 196, 110533. [CrossRef] [PubMed]

26. Xiao, Z.L.; Wang, Y.L.; Shen, Y.D.; Xu, Z.L.; Dong, J.X.; Wang, H.; Situ, C.; Wang, F.; Yang, J.Y.; Lei, H.T.; et al. Specifc monoclonal antibody- based enzyme immunoassay for sensitive and reliable detection of Alternaria mycotoxin iso-tenuazonic acid in food products. Food Anal. Methods 2018, 11, 635-645. [CrossRef]

27. Lu, P.; Yang, S.; Hu, D.Y.; Ding, X.Y.; Shi, M.M. Synthesis of Hapten and Development of Immunoassay Based on Monoclonal Antibody for the Detection of Dufulin in Agricultural Samples. J. Agric. Food Chem. 2013, 61, 10302-10309. [CrossRef] [PubMed]

28. Luo, L.; Shen, Y.D.; Wang, H.; Xiao, Z.L.; Sun, Y.M.; Lei, H.T.; Yang, J.Y.; Xu, Z.L. Production of Polyclonal Antibody and Development of a Competitive Enzyme-Linked Immunosorbent Assay for Benzoic Acid in Foods. Food Anal. Methods 2015, 8, 1101-1111. [CrossRef]

29. Shen, Y.D.; Xiao, B.; Xu, Z.L.; Lei, H.T.; Wang, H.; Yang, J.Y.; Sun, Y.M. Hapten synthesis and development of an indirect competitive enzyme-linked immunosorbent assay for chlorpromazine in pork, chicken and swine liver. Anal. Methods 2011, 3 , 2797-2803. [CrossRef]

30. Wang, Y.; Xu, Z.L.; Xie, Y.Y.; Tian, Y.X.; Shen, Y.D.; Young, G.M.; Wang, H.; Lei, H.T.; Sun, Y.M. Development of polyclonal antibody-based indirect competitive enzyme-linked immunosorbent assay for sodium saccharin residue in food samples. Food Chem. 2011, 126, 815-820. [CrossRef]

31. Paek, S.H.; Lee, S.H.; Cho, J.H.; Kim, Y.S. Development of Rapid One-Step Immunochromatographic Assay. Methods 2000, 22, 53-60. [CrossRef]

32. Marco, M.P.; Gee, S.J.; Cheng, H.M.; Liang, Z.Y.; Hammock, B.D. Development of an enzyme-linked immunosorbent assay for carbaryl. J. Agric. Food Chem. 1993, 41, 423-430. [CrossRef]

33. Jiang, X.X.; Shi, H.Y.; Wu, N.; Wang, M.H. Development of an enzyme-linked immunosorbent assay for diniconazole in agricultural samples. Food Chem. 2011, 125, 1385-1389. [CrossRef]

34. Henniona, M.C.; Barcelo, D. Strengths and limitations of immunoassays for effective and efficient use for pesticide analysis in water samples: A review. Anal. Chim. Acta 1998, 362, 3-34. [CrossRef]

35. Qi, Y.H.; Shan, W.C.; Liu, Y.Z.; Zhang, Y.J.; Wang, J.P. Production of the polyclonal antibody against Sudan 3 and immunoassay of Sudan dyes in food samples. J. Agric. Food Chem. 2012, 60, 2116-2122. [CrossRef] [PubMed]

36. Cui, X.; Wu, P.; Lai, D.; Zheng, S.; Chen, Y.; Eremin, S.A.; Peng, W.; Zhao, S. Development of a highly specific fluorescence immunoassay for detection of Diisobutyl Phthalate in edible oil samples. J. Agric. Food Chem. 2015, 63, 9372-9378. [CrossRef] [PubMed]

37. Zhang, Y.Q.; Xu, Z.L.; Wang, F.; Cai, J.; Dong, J.X.; Zhang, J.R.; Si, R.; Wang, C.L.; Wang, Y.; Shen, Y.D.; et al. Isolation of Bactrian Camel Single Domain Antibody for Parathion and Development of One-Step dc-FEIA Method Using VHH-Alkaline Phosphatase Fusion Protein. Anal. Chem. 2018, 90, 12886-12892. [CrossRef] [PubMed]

38. GB/T 23200.110-2018; Determination of Forchlorfenuron in Foods of Plant Origin-Liquid Chromatography Tandem Mass Spectrometry. National Standards of the People's Republic of China: Beijing, China, 2018.

39. Chen, X.J. Application of Immunology in Plant Science; China Agricultural University Press: Beijing, China, 1998.

40. Barnych, B.; Vasylieva, N.; Joseph, T.; Hulsizer, S.; Nguyen, H.M.; Cajka, T.; Pessah, I.; Wulff, H.; Gee, S.J.; Hammock, B.D. Development of tetramethylenedisulfotetramine (TETS) hapten library: Synthesis, electrophysiological studies and immune response in rabbits. Chem.-A Eur. J. 2017, 23, 8466-8472. [CrossRef] [PubMed]

41. Vasylieva, N.; Barnych, B.; Rand, A.A.; Inceoglu, B.; Gee, S.J.; Hammock, B.D. Sensitive Immunoassay for Detection and Quantification of the Neurotoxin, Tetramethylenedisulfotetramine. Anal. Chem. 2017, 89, 5612-5619. [CrossRef] [PubMed] 
42. Vasylieva, N.; Ahn, K.C.; Barnych, B.; Gee, S.J.; Hammock, B.D. Development of an Immunoassay for the Detection of the Phenylpyrazole Insecticide Fipronil. Environ. Sci. Technol. 2015, 49, 10038-10047. [CrossRef]

43. Chen, Z.J.; Fu, H.J.; Luo, L.; Sun, Y.M.; Yang, J.Y.; Zeng, D.P.; Shen, Y.D.; Xu, Z.L. Development of competitive indirect ELISAs with a flexible working range for the simple quantification of melatonin in medicinal foods. Anal. Methods 2017, 9, 1617-1626. [CrossRef]

44. Liang, C.Z.; Jin, R.Y.; Gui, W.J.; Zhu, G.N. Enzyme-Linked Immunosorbent Assay Based on a Monoclonal Antibody for the Detection of the Insecticide Triazophos: Assay Optimization and Application to Environmental Samples. Environ. Sci. Technol. 2007, 41, 6783-6788. [CrossRef]

45. Chen, L.Y.; Wang, M.C.; Xiang, H.F.; Lin, X.J.; Cao, D.H.; Ye, L.Y. Prediction of effect-site concentration of sufentanil by doseresponse target controlled infusion of sufentanil and propofol for analgesic and sedation maintenance in burn dressing changes. Environ. Sci. Technol. 2014, 40, 455-459. [CrossRef]

46. Yang, X.; Wang, Y.; Song, C.; Hu, X.; Wang, F.; Zeng, X. Hapten synthesis and the development of an ultrasensitive indirect competitive ELISA for the determination of diethylstilbestrol in food samples. Sci. Rep. 2020, 10, 3270. [CrossRef]

47. Mari, G.M.; Li, H.; Dong, B.; Yang, H.; Talpur, A.; Mi, J.; Guo, L.; Yu, X.; Ke, Y.; Han, D.; et al. Hapten synthesis, monoclonal antibody production and immunoassay development for direct detection of 4-hydroxybenzehydrazide in chicken, the metabolite of nifuroxazide. Food Chem. 2021, 355, 129598. [CrossRef] [PubMed]

48. Xu, Z.L.; Shen, Y.D.; Sun, Y.M.; Campbell, K.; Tian, Y.X.; Zhang, S.W.; Lei, H.T.; Jiang, Y.M. Novel hapten synthesis for antibody production and development of an enzymelinked immunosorbent assay for determination of furaltadone metabolite 3-amino-5morpholinomethyl-2-oxazolidinone (AMOZ). Talanta 2013, 103, 306-313. [CrossRef] [PubMed]

49. Sheng, Y.J.; Jiang, W.X.; Saeger, S.D.; Shen, J.Z.; Zhang, S.X.; Wang, Z.H. Development of a sensitive enzyme-linked immunosorbent assay for the detection of fumonisin B1 in maize. Toxicon 2012, 60, 1245-1250. [CrossRef] [PubMed]

50. Huo, J.Q.; Barnych, B.; Li, Z.F.; Wan, D.B.; Li, D.Y.; Vasylieva, N.; Knezevic, S.Z.; Osipitan, O.A.; Scott, J.E.; Zhang, J.L.; et al. Hapten Synthesis, Antibody Development, and a Highly Sensitive Indirect Competitive Chemiluminescent Enzyme Immunoassay for Detection of Dicamba. J. Agric. Food Chem. 2019, 67, 5711-5719. [CrossRef] [PubMed] 